\title{
Searching of the Genetically Modified Organisms and Their Products' Status and Evaluation of Food Safety and Regulations in Turkey in terms of the Forensic Sciences
}

\author{
Betül BITTIR SOYLU1, Itır ERKAN², Emel Hülya YÜKSELOĞLU*,1
}

\author{
${ }^{1}$ Institute of Legal Medicine and Forensic Sciences, Istanbul University-Cerrahpasa, Istanbul, Turkey \\ ${ }^{2}$ Department of Healthcare Management, Faculty of Health Sciences, Istanbul Yeni Yuzyil University, Istanbul, Turkey \\ ORCID ID: Betül BITIR SOYLU: https:// orcid.org/0000-0002-3905-3017; Itır ERKAN: https://orcid.org/0000-0002-5902-1936; Emel Hülya \\ YÜKSELOĞLU: https:// orcid.org/ 0000-0003-2009-6065
}

\begin{abstract}
Received: 02.09.2020
Accepted: 02.10.2020

Published online: 14.10 .2020

Issue published: 31.12 .2020

Abstract: Increased Genetically Modified (GM) plant production and the widespread trade and use of Genetically Modified Organisms (GMOs) in the food and animal feed markets are questioned about food safety by consumers. GMOs have been the subject of various cases in the areas of public health, environment, and finance. Turkey has also regulations and serious penalties about GMOs and its product-usage so it is also questioned by forensic sciences. The purpose of this study is to investigate the current situation by making GMO analyses in risky product groups. Products containing corn and soy content, known as risky product groups, were obtained from markets in Istanbul. GMO screening analysis of 35 products selected between July-September 2018 was performed by Real-Time PCR method. Positive results were detected in 2 animal feed samples. In these samples, the amount of GMO (35S region) was determined as below $0.1 \%$. According to the legal regulations, GMO below $0.9 \%$ rates may result from contamination that cannot be prevented.
\end{abstract}

Keywords: Biotechnology, genetics, polymerase chain reaction (PCR), public health.

\section{Genetiği Değiştirilmiş Organizmalar ve Ürünlerinin Türkiye Piyasasındaki Durumuna Bir Bakış ve Gıda Güvenliği Düzenlenmelerinin Adli Bilimler Açısından Değerlendirilmesi}

Öz: Genetiği değiştirilmiş (GD) bitki üretim ve ekiminin artması, genetiği değiştirilmiş organizmaların (GDO) gıda ve yem pazarında yaygın ticareti ve kullanımı gıda güvenliği konusunda tüketiciler tarafından sorgulanmaktadır. GDO'lar halk sağlığı, çevre ve finans alanlarında çeşitli davaların konusu olmuştur. Türkiye, pek çok ülke gibi GDO'lar ve ürünlerine dair hukuki düzenlemelere ve ciddi yaptırımlara sahiptir. Bu sebeple adli bilimler açısından pek çok açıdan önemli bir konu olmaktadır. Bu çalışmanın amacı riskli ürün gruplarında GDO analizleri yaparak şu anki durumu araştırmaktır. Riskli ürün grupları olarak bilinen mısır ve soya içeriği barındıran ürünler İstanbul'daki marketlerden temin edilmiştir. Temmuz-Eylül 2018 tarihleri arasında seçilen 35 adet ürünün, Real-Time PCR yöntemi ile GDO tarama analizi yapılmıştır. İki hayvan yem örneğinde pozitiflik tespit edilmiştir. Bu örneklerde GDO miktarı (35S bölgesinde) \%0.1'den düşük olarak tespit edilmiştir. Yasal düzenlemelere göre \%0.9'un altında bulunan GDO oranlarının ise önlenemeyecek kontaminasyonlardan kaynaklanabileceği kabul edilmektedir.

Anahtar kelimeler: Biyoteknoloji, genetik, polimeraz zincir reaksiyonu (PCR), halk sağlı̆̆ı.

\section{Introduction}

As a result of the advances in biotechnology with the advent of the recombinant deoxyribonucleic acid (rDNA) technology in the 1960s, genetically modified (GM) organisms (GMOs) started to be spoken for the first time in the scientific world. With the production and cultivation of various GM grains, the cultivation of food and feed-based GM plants has gained speed. While biotechnological grains were 1.7 million hectares in 1996 when it was first cultivated, GM grain cultivation increased continuously in 23 years and reached 2.5 billion hectares as of 2019. It is seen that the most cultivated species are soybeans, corn, cotton, and canola (ISAAA, 2019).

However, today, one of the most discussed technology products has been GMOs (Arun et al., 2015). Due to food safety, environmental, and public health issues, the use of GM food and feed is made in accordance with certain laws in many countries of the world and is subject to national and international monitoring and control (Ahmed, 2002; Erdogan, 2015). As in our country, many countries have criminal responsibility in the legal system and various sanctions and penalties are imposed on those who do not comply with the rules and regulations determined in this regard (Erdogan, 2015). This product, which can be a common subject of philosophy in terms of biotechnology, ecology, law, and even ethics, has also been in the interest of forensic science, especially since it concerns food safety, public health, and environmental issues closely. Doubts about GMO's are changes in the nutritional quality of food, the possibility of antibiotic resistance, the potential toxicity of GM foods, potential allergenicity of GM, possible carcinogen effect, unwanted gene transitions to wild plants, the formation of new viruses and toxins, restriction of access to seeds, threats to biodiversity, other ethical and religious sensitivities, not labeling, animal rights, the situation of organic and traditional farmers, and fear of the unknown (Uzogara, 2000; Fraiture, Herman, Taverniers, Loose, Deforce, \& Roosens, 2015). The main damages of GMOs reported in different studies are possible allergic reactions, potential 
toxicity, antibiotic resistance, gene patenting, and impacting biodiversity (Raza, Razzaq, Mehmood, Zou, Zhang, Lv, \& Xu, 2019; Kumar et al., 2020). There are many things affecting the Polymerase Chain Reaction (PCR) amplification such as the set-up of the laboratory, PCR reactants, and sample types and primers; however, the DNA extraction method is very important in GMO analysis as sample types are diverse and DNA quality is of very high concern. Several methods have been developed for GMO detection and quantitation, mostly based on DNA techniques, since protein-based methods are not reliable for highly processed food analysis (Mandaci, Cakir, Turgut-Kara, Meriç, \& Ari, 2014).

This study was carried out with the aim of conducting market research by making GMO Screening analyses in risky product groups using Real-Time PCR technique in order to contribute to food safety.

\section{Material and Methods}

\subsection{Samples}

In this research, all analyses were made at a private food analysis laboratory in Istanbul from July until September 2018. 35 products were used (Table 1). Analyses were made in accordance with relevant laws and regulations. Two parallels were used for each sample to ensure the reliability of the results. The samples that involved soy and corn were selected because those groups are identified as the riskiest ones for GMO content by the Ministry of Agriculture and Forestry (2006). Products were purchased randomly from supermarkets in Istanbul, Turkey.

\subsection{DNA Extraction}

Samples were homogenized to represent the original samples. Mechanical breaking is the first step for extraction. Three different DNA extraction kits were used. Weighing is made according to the kits' procedure. DNA extraction kits are Genespin DNA Extraction Kit (Eurofins), Surefood Prep Advanced DNA Extraction Kit (Congen), and Food DNA Kit IPC16 Extraction Kit (Innuprep). Extraction steps are preparing of material, lysis, cleaning of DNA, and elution. Processes were made in accordance with the kits' protocols.

\subsection{Spectrophotometric Measurement}

The amount and purity of the solution of the extracted DNA were measured spectrophotometrically using a Shimadzu Bio-spec Nano spectrophotometer at $260 \mathrm{~nm}$ $\left(\mathrm{A}_{260}\right)$ and $280 \mathrm{~nm}\left(\mathrm{~A}_{280}\right)$ wavelengths. DNA purity was determined using $\mathrm{A}_{260} / \mathrm{A}_{280}$ ratio. Samples with $\mathrm{A}_{260} / \mathrm{A}_{280}$ ratios between 1.70-2.00 were used in the study. Plant screening tests are performed according to the procedure in case of some samples with mixed and highly processed food. These examples are mentioned in the discussion section.

Table 1. Sample details

\begin{tabular}{|c|c|c|c|}
\hline Sample ID & Product type & Risky GMO content & Origin \\
\hline Sample 1 & Chocolate & Soy lecithin & Turkey \\
\hline Sample 2 & Chocolate & Canola oil, soy lecithin & Turkey \\
\hline Sample 3 & Meat & Soy protein & Turkey \\
\hline Sample 4 & Biscuit / Chocolate & Soy lecithin & Turkey \\
\hline Sample 5 & Meat & Soy protein & Turkey \\
\hline Sample 6 & Biscuit / Chocolate & Soy flour, Soy lecithin & Turkey \\
\hline Sample 7 & Biscuit / Chocolate & Canola oil, cotton oil, soy lecithin & Turkey \\
\hline Sample 8 & Meat & Soy protein & Turkey \\
\hline Sample 9 & Biscuit / Chocolate & Soy lecithin & Turkey \\
\hline Sample 10 & Biscuit / Chocolate & Soy lecithin & Turkey \\
\hline Sample 11 & Soy & Soybean sprouts & Turkey \\
\hline Sample 12 & Soy & Soybean & Turkey \\
\hline Sample 13 & Soy & Soybean sprouts & Far East \\
\hline Sample 14 & Soy & Soy protein & Turkey \\
\hline Sample 15 & Cereals & Soy lecithin & Turkey \\
\hline Sample 16 & Cereals & Corn flour, soy lecithin & Turkey \\
\hline Sample 17 & Cereals & Corn semolina & Turkey \\
\hline Sample 18 & Chips & Corn, soy & Turkey \\
\hline Sample 19 & Cracker & Soy lecithin & Turkey \\
\hline Sample 20 & Cracker & Cotton oil, canola oil, a trace amount of soy & Turkey \\
\hline Sample 21 & Noodle & Soy lecithin, soybean & Far East \\
\hline Sample 22 & Corn Flour & Corn flour & Turkey \\
\hline Sample 23 & Corn Flour & Corn flour & Turkey \\
\hline Sample 24 & Cat Food & Cereals & Turkey \\
\hline Sample 25 & Cat Food & Cereals & Turkey \\
\hline Sample 26 & Cat Food & Cereals & Turkey \\
\hline Sample 27 & Soy & Soybean sprouts & Turkey \\
\hline Sample 28 & Noodle & Soy lecithin, soybean & Far East \\
\hline Sample 29 & Bread & May contains soy & Turkey \\
\hline Sample 30 & Noodle & Soy lecithin & Turkey \\
\hline Sample 31 & Baked Products & Soy lecithin & Turkey \\
\hline Sample 32 & Bread & May contains soy & Turkey \\
\hline Sample 33 & Baked Products & Soy lecithin & Turkey \\
\hline Sample 34 & Chips & Corn, soy lecithin & Turkey \\
\hline Sample 35 & Cereals & Corn flour, Soy lecithin & Turkey \\
\hline
\end{tabular}

\subsection{S/NOS/FMV/Inhibition PCR-mix Preparation}

DNA samples with a concentration of more than $40 \mathrm{ng} / \mu \mathrm{l}$ were diluted with water and used in the PCR reaction in that way. Samples with a concentration of less than 20 $\mathrm{ng} / \mu \mathrm{l}$ were evaporated using a DNA concentrator and used by evaluating the amount and purity. In addition, DNA was used by passing through the cleaning column in samples with high pollution. 
Eurofins GMO Screen RT 35S/NOS/FMV IPC, PCR GMO Screen kit was used. DNA isolates of each technical replicates were added in different wells for real-time PCR analysis. The sample was added by mixing the appropriate amount of basic and oligo mix according to the kit. An aliquot of $25 \mu \mathrm{l}$ of the reaction solution contained $12.5 \mu \mathrm{l}$ of the basic mixture, $7.5 \mu \mathrm{l}$ of oligo mixture (35S/NOS/FMV primers), $5 \mu$ l of sample or control were added to the plate wells per wellhead. Additionally, positive control (PC) and negative template control (NTC) wells were also included to make sure the kit is working properly for every sample. According to the procedure, if it was needed, positive extraction control (PEC), negative extraction control (NEC), and environmental control (EC) were also added.

\subsection{Real-Time PCR Analysis}

Real-Time PCR method was applied using Agilent Aria$\mathrm{mx}$ Real-Time PCR for analysis according to Eurofins GMO Screen RT 35S/NOS/FMV IPC Kit Manual. Initial denaturation of $10 \mathrm{~min}$ at $95^{\circ} \mathrm{C}$ and subsequent denaturation for $15 \mathrm{sec}$ at $95^{\circ} \mathrm{C}$, annealing and elongation for $90 \mathrm{sec}$ at $60^{\circ} \mathrm{C}$ with a total repetition of 45 cycles, and finally cooling for $10 \mathrm{~s}$ at $40^{\circ} \mathrm{C}$. Those accounting for $\mathrm{Ct}<38$ were considered positive as a result of the analysis. Results were analyzed by proper software (AiraMX, Agilent).

\section{Results and Discussion}

The aim of this study is to investigate the status of GMO risky products in the market and to evaluate the forensic sciences by calculating the quantification of positive samples. This kind of research provides to see the reflections of food safety and legal control issues in the market and is important to draw attention to the issue. Considering the limits of the regulations in the relevant law, attention was drawn to the limits of criminal liability. The study was carried out by following the routine analysis procedures used in the official control. The analyses were found to be positive in two feeds and other samples were reported as negative. Positive results were found in the feed samples in different studies in Turkey (Meric et al., 2014; Erkan \& Dastan, 2017; Avsar, Sadeghi, Turkec, \& Lucas, 2020). Turkey became a party to the Convention on Biological Diversity and the Cartagena Protocol. States such as the USA, Canada, and the Russian Federation are not a party to the protocol (Erdogan, 2015). Turkey's approach to the precautionary approach in terms of the long-term negative effects of modern biotechnological methods is positive. Legal regulations applied by the EU, USA, or any country affect the international trade of GMOs. Many countries and companies prefer to comply with the EU regulations (Gostek, 2016). When evaluated from this point of view, the cautious approach in line with the EU principles applied in our country directs the policies of companies producing GM products and their researches on health and environment.

In this study, sample analyses were carried out by using the kit analysis reaction table. Cut off values were calculated for each sequence by using this table and inhibition and fluorescence values were reviewed. Two samples of animal food were detected as GMO contained in 35 samples. GMO results are shown in Table 2. Sample
28 's one parallel was positive in GMO Screen so the analysis was repeated. The second analysis was found as negative. Sample 24 and 25 were reported as positive. The other 33 products' GMO analyses results were negative. $\mathrm{Ct}$ values of sample 24 and 25 are presented in Table 3 and 4, GMO Screen analyses of these samples are presented in Figure 1 and 2. GMO values are calculated as prediction by referring, according to a previous study (Branquinho, Ferreira, \& Cardarelli-Leite, 2010) and GMO values are presented in Table 5. GMO amounts of Sample 24 and 25 ( $35 \mathrm{~S}$ region) were determined as below $0.1 \%$. According to legal regulations, GMO below $0.9 \%$ rates may result from contamination that cannot be prevented.

Table 2. Sample details

\begin{tabular}{|c|c|c|}
\hline Sample ID & Product type & Screen analysis \\
\hline Sample 1 & Chocolate & Negative \\
\hline Sample 2 & Chocolate & Negative \\
\hline Sample 3 & Meat & Negative \\
\hline Sample 4 & Biscuit /Chocolate & Negative \\
\hline Sample 5 & Meat & Negative \\
\hline Sample 6 & Biscuit / Chocolate & Negative \\
\hline Sample 7 & Biscuit / Chocolate & Negative \\
\hline Sample 8 & Meat & Negative \\
\hline Sample 9 & Biscuit / Chocolate & Negative \\
\hline Sample 10 & Biscuit / Chocolate & Negative \\
\hline Sample 11 & Soy & Negative \\
\hline Sample 12 & Soy & Negative \\
\hline Sample 13 & Soy & Negative \\
\hline Sample 14 & Soy & Negative \\
\hline Sample 15 & Cereals & Negative \\
\hline Sample 16 & Cereals & Negative \\
\hline Sample 17 & Cereals & Negative \\
\hline Sample 18 & Chips & Negative \\
\hline Sample 19 & Cracker & Negative \\
\hline Sample 20 & Cracker & Negative \\
\hline Sample 21 & Noodle & Negative \\
\hline Sample 22 & Corn Flour & Negative \\
\hline Sample 23 & Corn Flour & Negative \\
\hline Sample 24 & Cat Food & Positive \\
\hline Sample 25 & Cat Food & Positive \\
\hline Sample 26 & Cat Food & Negative \\
\hline Sample 27 & Soy & Negative \\
\hline Sample 28 & Noodle & Negative \\
\hline Sample 29 & Bread & Negative \\
\hline Sample 30 & Noodle & Negative \\
\hline Sample 31 & Baked Products & Negative \\
\hline Sample 32 & Bread & Negative \\
\hline Sample 33 & Baked Products & Negative \\
\hline Sample 34 & Chips & Negative \\
\hline Sample 35 & Cereals & Negative \\
\hline
\end{tabular}

Due to the increasing trade volumes of GMOs and their products, food safety issues and related legal regulations in different countries are becoming more important. Hence, many studies focusing on the search of GMOs in the market in Turkey or other countries have been published (Branquinho et al., 2010; Arun, Yilmaz, \& Muratoglu, 2013; Meric, Cakir, Turgut-Kara, \& Ari, 2014). As it is the most produced transgenic plant species, we see that these studies focus specially on foods containing corn and soy (Turkec, Kazan, Karacanli, \& Lucas, 2015). In this study, corn and soy origin samples were examined. For this purpose, food products containing corn and soy were randomly selected from markets. In some studies, it was done by scanning the same products at different times to follow the market status of the products in different years (Santa-Maria, Lajo-Morgan, \& Guardia, 2014; Bekhit, 2019). Thus, it has been ensured that the changing GM food situation in the market is followed in different periods. For example, GMO detection in soy-based products has increased in some years and decreased in some others 
(Tung-Nguyen, Son, Raha, Lai, \& Clemente, 2008). In this study, products were procured step by step and the whole process was completed in about three months and no screening was performed in different years. This may have created a disadvantage for the study. Examining the same risk product groups for different years will provide a more detailed examination. Besides, increasing the number of samples will provide a more accurate analysis of the situation in the market.

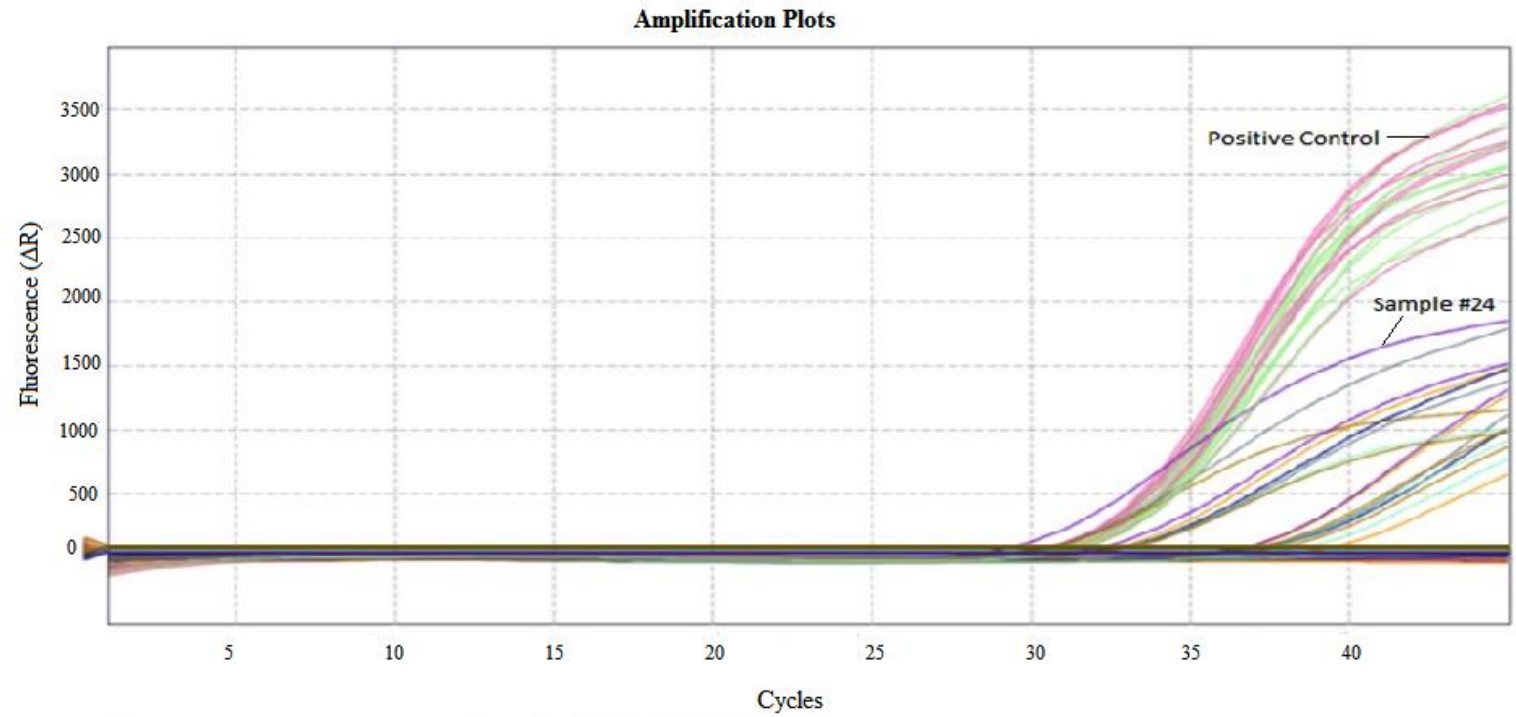

Figure 1. Amplification curves for Sample 24 obtained from GMO Screen analysis

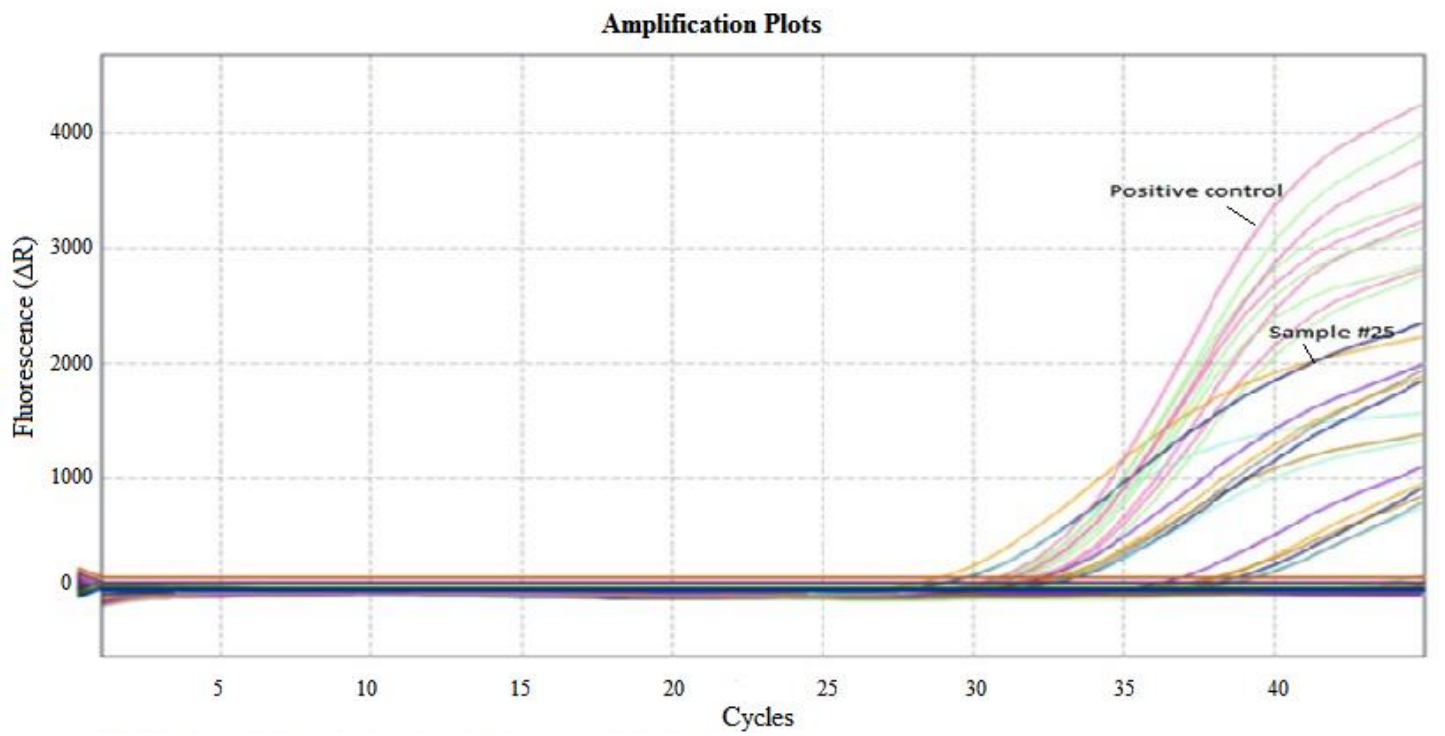

Figure 2. Amplification curves for Sample 25 obtained from GMO Screen analysis

Table 3. GMO Screen Ct values for Sample 24. PC: Positive Control, NTC: Negative Template Control, PEC: Positive Extraction Control, IPC: Internal Positive Control

\begin{tabular}{|c|c|c|c|c|c|c|c|c|c|}
\hline & & \multicolumn{4}{|c|}{ Parallel 1} & \multicolumn{4}{|c|}{ Parallel 2} \\
\hline \multirow{5}{*}{ Analysis } & & $35 S$ & FMV & NOS & IPC & $35 \mathrm{~S}$ & FMV & NOS & IPC \\
\hline & Sample & 38.89 & - & 38.79 & 30.59 & - & - & 38.03 & 30.79 \\
\hline & PC & 32.15 & 33.41 & 33.19 & 31.51 & 31.62 & 33.58 & 33.29 & 31.47 \\
\hline & NTC & - & - & - & 30.45 & - & - & - & 30.82 \\
\hline & PEC & 28.86 & 30.98 & 30.79 & 31.46 & & & & \\
\hline
\end{tabular}

Table 4. GMO Screen Ct values for Sample 25. PC: Positive Control, NTC: Negative Template Control, PEC: Positive Extraction Control, IPC: Internal Positive Control

\begin{tabular}{|c|c|c|c|c|c|c|c|c|c|}
\hline & & \multicolumn{4}{|c|}{ Parallel 1 } & \multicolumn{4}{|c|}{ Parallel 2} \\
\hline \multirow{5}{*}{ Analysis } & & $35 \mathrm{~S}$ & $\overline{\text { FMV }}$ & NOS & IPC & $35 \mathrm{~S}$ & $\overline{\text { FMV }}$ & NOS & IPC \\
\hline & Sample & 36.24 & 37.97 & 37.60 & 31.02 & 36.21 & 37.78 & 37.34 & 31.17 \\
\hline & PC & 32.15 & 33.41 & 33.19 & 31.51 & 31.62 & 33.58 & 33.29 & 31.47 \\
\hline & NTC & - & - & - & 30.45 & - & - & - & 30.82 \\
\hline & PEC & 28.86 & 30.98 & 30.79 & 31.46 & & & & \\
\hline
\end{tabular}


Table 5. \%GMO Values of Sample 24 and 25

\begin{tabular}{|c|c|c|c|c|c|c|c|}
\hline \multirow[t]{2}{*}{ Samples } & & \multicolumn{3}{|c|}{ Parallel 1} & \multicolumn{3}{|c|}{ Parallel 2} \\
\hline & & P35S & tNOS & pFMV & P35S & tNOS & pFMV \\
\hline \multirow[t]{2}{*}{ Sample 24} & Analysis 2 & 35.75 & 37.69 & 34.84 & 36.32 & 37.60 & 33.81 \\
\hline & $\% \mathrm{GMO}$ & p35s & & & & & \\
\hline \multirow[t]{2}{*}{ Sample 25} & Analysis 2 & 36.75 & 39.10 & 37.54 & 35.37 & 39.69 & 36.67 \\
\hline & $\% \mathrm{GMO}$ & p35S & & & & & \\
\hline
\end{tabular}

The study was designed in different risk product groups to provide diversity in product groups. As another approach, examining a single product group would yield more meaningful results due to more sample examinations in the same product group. Also, during the study, there were difficulties in obtaining the soy product, which is the primary product group. Products such as soy meat in many grocery stores were not available for about two months and it was stated that they were not in stock. Thus, previously the products which were made in Turkey were selected and; then, imported products were used. The reason why the Turkey origin products were chosen previously is the strict regulation of the imported ones' control and the risky of usage GM feed content as food ingredients (Erkan \& Dastan, 2017). That has been suspected in the news by the media. There is no GM landing and productions of the source of GM are thought of as imported GM feed. The contents of corn and soy could be as food additives or preservatives. Therefore, if it is used in the food ingredients industry, it will be harder to detect them because of the process (Gryson, 2010). It has been shown that over-processed samples and samples have many components in GMO detection becomes difficult because of impureness and degraded DNA. According to the Ministry's procedure, if the DNA amount and purity values from DNA extraction obtained are not suitable, plant DNA search test is performed and if the DNA cannot be detected, it is reported as appropriate in the report (Linnhoff, Volovich, Martin, \& Smith, 2017).

During the import process, the firm makes a statement that it does not contain GMO and it is approved if it is found consistent. In cases where plant DNA cannot be detected in the analysis reports performed under this procedure, the products reported as "DNA Not Detected" does not mean that there is no GMO. This statement indicates that the product does not contain DNA that can be amplificated in PCR. In the processed samples in GMO detection, this negative situation draws attention to the product components. It is difficult to obtain DNA samples from the products such as starch, lecithin-containing samples, chocolate, and sauce (Greiner, Konietzny, \& Villavicencio, 2005). In the present study, in case of poor DNA quality, i.e. $\mathrm{A}_{260} / \mathrm{A}_{280}$ value is out of the ideal conditions of 1.7-2.0 range, an inhibition test is performed using the internal positive control (IPC) provided in the kit, without the need for a separate analysis. Thus, it was confirmed that there was no inhibition.

In eight of the thirty-five products, spectrophotometer DNA measurements differed from the expected ideal values. DNA inhibition parameters were examined and reanalyzed with these samples or making of plants screening if necessary for the procedure. Four of these products are chocolate and they are mixed samples $(1,2,4$, and 9) that have components that can cause inhibition in the PCR reaction. Two of them are from the soy group and they are soy tofu and canned soy with various preservatives (sample
12, 13); two of them are cereal with chocolate content (sample 17, 35). DNA extracts of Sample 1 and Sample 2 were repeated with three kits that were Analytik Jena, Genespin, and Congen. Isolates obtained with the Congen kit were positive in the plant screening test and the presence of plant DNA was proven and these samples were used in GMO Screening analysis. Despite the low-quality values at samples $4,9,12,17$, there was no inhibition in reaction. One of the parallels' values of the first isolations from Sample 13 was below $10 \mathrm{ng} / \mu \mathrm{l}$. Although an attempt was made to concentrate the DNA by vacuum, an increase in the amount of DNA was not observed. Subsequently, the samples that were incubated overnight in lysis solution were isolated again the next day and these samples were found appropriate and used in GMO Screen analysis. The Sample 16 was isolated with Genespin and Congen. No inhibition was observed in the Congen isolation results and their action occurred. In addition, analysis of the three sequences (p35S, tNOS, pFMV) included in the GMO Screening kit was analyzed. Negative examples mean that these sequences are not available. The Ministry also carries out analyses of different types of GM soy, corn, and cotton where these sequences are not available (Fraitur et al., 2015). These varieties are GM Soy MON87701, MON87708, MON87769, CV127, DP305423, DAS44406, DAS68416, DAS81419; GM Cotton 281-24-236, 3006-210-23, GHB614; GM Corn DAS40278, MON87427 (Meyer, 1999). p35S, tNOS, and pFMV sequences that are screened are not located in the gene regulatory regions of these species. In the first stages of the project, only general screening, GMO screening test was preferred and screening for different GM types was not made because of the limited budget. These GM screenings are mandatory for imported products to allow them to enter the country but it can be preferred for other products. Moreover, as mentioned earlier, common screening methods target first Generation GMOs. However, 2nd and 3rd Generation GMO detection are more difficult. Difficulties are experienced in GMO analysis with the increase of new genes and a variety of gene editing regions. In the following years, analyzes will become more complicated due to the preference of methods based on the analysis of targets, especially micro-arrays. It has been observed that some companies make changes in the product content information on the packages. For example, previously it was observed that the product contained soy lecithin and later it was seen that product content changed and included sunflower lecithin. This shows that the relevant regulations are an important step towards being effective and dissuasive.

In previous years, more GM products were found in similar products randomly collected from the market shelves and it is seen that this rate decreased with this study. GM quantification tests were not carried out since the relevant sequences could not be detected in food samples. In the analyzed feed samples, the Ct values followed the positive control values whose GM amount was 50 copies. In different publications, there are theoretically GM 
quantification calculations (Branquinho et al., 2010; Cottenet, Blancpain, \& Chuah, 2019). These calculations were made by considering factors such as target sequence fragment size, sequence, and method type (Cankar, Stebih, Dreo, Zel, \& Gruden, 2006). The same methods were used for quantification in our study.

Some GM cereals' cultivation is banned in countries such as Switzerland, Holland, France, and Hungary (Gostek, 2016). Commercial GM cereal cultivation and production are also prohibited in our country. The purpose of these prohibitions is to prevent the damage of biodiversity. It is mentioned that the reason for the presence of GM species in food products may be imported feed products as it is forbidden to plant GM to cultivate. In this case, domestic market tests become important as well as imported product tests.

The Ministry publishes adulteration lists for different food analyses and its brands are shared with the public. However, the brand names of GMO samples and the number of products detected are not shared with the public because of the reason that the brand values can be damaged. If test results are transparent and accessible to the public, it will provide confidence for consumers and ensure that companies pay maximum attention to the issue. The species under control in our country are selected by taking reference of the EU official institution. The test methods and the related official regulations should be updated frequently and the latest developments need to be followed quickly by considering the developing technologies mentioned.

Considering criminal liability, legal responsibilities may change depending upon technical advances. For this reason, in terms of forensic sciences, both technical advances in methods used in GMO determination and the monitoring and new administrative sanctions and penal provisions in the light of these developments are required. The functionality of the follow-up and control mechanism is important to prevent damages that may arise from the risks of the release of GMOs into the environment or any uncontrolled use. As mentioned, GMOs are still important in forensic sciences as it is an important environmental and public health issue.

\section{References}

Ahmed, F.E. (2002). Detection of genetically modified organisms in foods. Trends in Biotechnology, 20(5), 215-223. https://doi.org/10.1016/S0167$\underline{7799(01) 01920-5}$

Arun, Ö.Ö., Yılmaz, F., \& Muratoğlu, K. (2013). PCR detection of genetically modified maize and soy in mildly and highly processed foods. Food Control, 32(2), 525-531. https://doi.org/10.1016/ i.foodcont.2013.01.023

Arun, Ö.Ö., Muratoğlu, K., \& Eker, F.Y. (2015). Overview of the concept of genetically modified organisms. Journal of Veterinary Faculty of Istanbul University, 41(1), 113-123.

Avsar, B., Sadeghi, S., Turkec, A., \& Lucas, S.J. (2020). Identification and quantitation of genetically modified (GM) ingredients in maize, rice, soybean and wheat-containing retail foods and feeds in Turkey. Journal of Food Science and Technology, 57, 787-793. https://doi.org/10.1007/s13197-019-04080-2

Bekhit, M. (2019). Detection of Genetically Modified Foods Existence in Egypt Markets. Annals of Agricultural Science, Moshtohor, 57(3), 725-738. https://doi.org/10.21608/assjm.2019.98134

Branquinho, M., Ferreira, T.B.R., \& Cardarelli-Leite, P. (2010). Survey of compliance with labeling legislation in food containing GMOs in Brazil. Journal of Food Composition and Analysis, 23(3), 220-225. https://doi.org/10.1016/j.jfca.2009.09.004

Cankar, K., Stebih, D., Dreo, T., Zel, J., \& Gruden, K. (2006). Critical points of DNA quantification by real-time PCR effects of DNA extraction method and sample matrix on quantification of genetically modified organisms. BMC Biotechnology, 6, 37. https://doi.org/10.1186/1472$\underline{6750-6-37}$

Cottenet, G., Blancpain, C., \& Chuah, P. F. (2019). Performance assessment of digital PCR for the quantification of GM-maize and GM-soya events. Analytical and Bioanalytical Chemistry, 411(11), 2461-2469. https://doi.org/10.1007/s00216-019-01692-7

Erdoğan, S.M. (2015). GMO Legislation in the World, and Implementation of Trade Comparison and Turkey [EU Thesis]. T. C. Food, Agriculture and Livestock Ministry: General Directorate of European Union and Foreign Relations, ODTU (METU), Ankara.

Erkan, I., \& Dastan, K. (2017). Real-Time PCR detection of genetically modified organisms in several food products and their environmental effects in Turkey. Fresenius Environmental Bulletin, 26(4), 2589-2595.

Fraiture, M.A., Herman, P., Taverniers, I., Loose, M.D., Deforce, D., \& Roosens, N.H. (2015). Current and new approaches in GMO detection: Challenges and solutions. BioMed Research International, 2015, 392872. https://doi.org/10.1155/2015/392872

Gostek, K. (2016). Genetically modified organisms: How the United States' and the European Union's regulations affect the economy. Michigan State International Law Review, 24, 761.

Greiner, R., Konietzny, U., \& Villavicencio, A.L.C.H. (2005). Qualitative and quantitative detection of genetically modified maize and soy in processed foods sold commercially in Brazil by PCR-based methods. Food Control, 16, 753-759. https://doi.org/10.1016/j.foodcont. $\underline{2004.06 .015}$

Gryson, N. (2010). Effect of food processing on plant DNA degradation and PCR-based GMO analysis: A review. Analytical and Bioanalytical Chemistry, 396(6), 2003-2022. https://doi.org/10.1007/s00216-0093343-2

International Service for the Acquisition of Agri-biotech Applications (ISAAA) (2019). Global Status of Commercialized Biotech/GM Crops in 2018: Biotech Crop Area Reaches 2.5 Billion Hectares in 23 Years, Ithaca, NY.

Kumar, K., Gambhir, G., Dass, A., Tripathi, A.K., Singh, A., Jha, A.K., ... Rakshit, S. (2020). Genetically modified crops: Current status and future prospects. Planta, 251, 1-27. https://doi.org/10.1007/s00425020-03372-8

Linnhoff, S., Volovich, E., Martin, H.M., \& Smith, L.M. (2017). An examination of millennials' attitudes toward genetically modified organism (GMO) foods: Is it franken-food or super-food? International Journal of Agricultural Resources, Governance and Ecology, 13(4), 371-390. https://doi.org/10.2139/ssrn.2419593

Mandaci, M., Cakir, O., Turgut-Kara, N., Meriç, S., \& Ari, S. (2014). Detection of genetically modified organisms in soy products sold in Turkish market. Food Science and Technology, 34(4), 717-722. https://doi.org/10.1590/1678-457X.6441

Meric, S., Cakır, O., Turgut-Kara, N., \& Ari, S. (2014). Detection of genetically modified maize and soybean in feed samples. Genetics and Molecular Research, 13(1), 1160-1168. https://doi.org/10.4238/ 2014.february.25.2

Meyer, R. (1999). Development and application of DNA analytical methods for the detection of GMOs in food. Food Control, 10(6), 391399. https://doi.org/10.1016/S0956-7135(99)00081-X

Raza, A., Razzaq, A., Mehmood, S.S., Zou, X., Zhang, X., Lv, Y., \& Xu, J. (2019). Impact of climate change on crops adaptation and strategies to tackle its outcome: a review. Plants, 8, 34. https://doi.org/10.3390/ plants8020034

Santa-Maria, M.C., Lajo-Morgan, G., \& Guardia, L. (2014). Adventitious presence of transgenic events in the maize supply chain in Peru: A case study. Food Control, 41, 96-101. https://doi.org/10.1016/ j.foodcont.2014.01.006

Tung-Nguyen, C.T., Son, R., Raha, A.R., Lai, O.M., Clemente, M., \& Wong, V.L. (2008). Detection of genetically modified organisms (GMOs) using molecular techniques in food and feed samples from Malaysia and Vietnam. International Food Research Journal, 15(2), 155-166.

Turkec, A., Kazan, H., Karacanli, B., \& Lucas, S.J. (2015). DNA extraction techniques compared for accurate detection of genetically modified organisms (GMOs) in maize food and feed products. Journal of Food Science and Technology, 52(8), 5164-5171. https://doi.org/10.1007/ s13197-014-1547-8

Uzogara, S.G. (2000). The impact of genetic modification of human foods in the 21st century: A review. Biotechnology Advences, 18(3), 179-206. https://doi.org/10.1016/S0734-9750(00)00033-1 